九州大学学術情報リポジトリ

Kyushu University Institutional Repository

The Combination of Coagulation-Flocculation and Membrane Processes to Minimize Pollution of Tofu Wastewater

Sabarudin, Triargi, Batara

Department of Chemical Engineering, Faculty of Engineering, Universitas Indonesia

Kartohardjono, Sutrasno

Department of Chemical Engineering, Faculty of Engineering, Universitas Indonesia

https://doi.org/10.5109/2740942

出版情報 : Evergreen. 7 (1)，pp.56-60，2020-03. 九州大学グリーンテクノロジー研究教育センター バージョン：

権利関係 : 


\title{
The Combination of Coagulation-Flocculation and Membrane Processes to Minimize Pollution of Tofu Wastewater
}

\author{
Batara Triargi Sabarudin ${ }^{1}$, Sutrasno Kartohardjono, ${ }^{1, *}$ \\ ${ }^{1}$ Department of Chemical Engineering, Faculty of Engineering, Universitas Indonesia, Indonesia \\ *Author to whom correspondence should be addressed: \\ E-mail: sutrasno@che.ui.ac.id
}

(Received October 31, 2019; Revised January 23, 2020; accepted February 24, 2020).

\begin{abstract}
Tofu is one of the most general foods consumed by Indonesian, but much wastewater are produced in the process of making this delicate food. This study aims to find the effectiveness of coagulation-flocculation process and membrane processes, especially ultrafiltration (UF) and reverse osmosis (RO) membrane, to treat tofu wastewater. The coagulant agent used is alum which has been tested to find its optimum dosage. The initial measurement of tofu wastewater had TSS, turbidity, COD and TDS ranging from $880-1009 \mathrm{mg} / \mathrm{L}, 901-1131 \mathrm{FAU}, 5981-6525 \mathrm{mg} / \mathrm{L}$ and $2220-2640$ $\mathrm{mg} / \mathrm{L}$, respectively, while the $p \mathrm{H}$ in the ranges of 4.0 to 4.2 . The optimal dose of coagulant based on the experiments was $300 \mathrm{ppm}$. In the UF process, the concentration of all parameters except COD of produced water have already met the national standard. Furthermore, in the RO process, the produced water has already met the requirement of national standard for discharged water.
\end{abstract}

Keywords: coagulation-flocculation; revrese osmosis; tofu wastewater; ultra filtration

\section{Introduction}

Indonesia is a big country with a big amount of soybean consumption. Indonesia is one of the largest soybean consumers in the world, around $90 \%$ of which is used as an ingredient of soy bean cake and tofu. Tofu is a solid food, which made from the extraction of soybean, produced through sedimentation process of its protein ${ }^{1,2)}$. Due to the demand increase, the amount of tofu industries also growing in these recent years, especially, $1.41 \%$ growth in $2013^{3)}$.

Tofu is created through complex process with addition of many chemical compounds. In the process of making tofu, the wastewater is generated that comes out of soybean curd will be an environmental problem if disposed of directly because it will deteriorate very quickly due to the high water content and nutrients for bacterial growth ${ }^{4)}$. In generally, tofu wastewater have BOD (Biological Oxygen Demand) and COD (Chemical Oxygen Demand) around $6000-8000 \mathrm{mg} / \mathrm{L}$ and 7,500 $26,000 \mathrm{mg} / \mathrm{L}$, respectively ${ }^{1,}{ }^{5}$. Meanwhile, waste quality standards from the soybean processing industry, according to the Ministry of Environment, are $150 \mathrm{mg} / \mathrm{L}, 275 \mathrm{mg} / \mathrm{L}, 100 \mathrm{mg} / \mathrm{L}$ and 6 - 9 for BOD, COD, TSS and $\mathrm{pH}$, respectively $6,7)$. Therefore, protecting the environment is very important to minimize the negative impacts of tofu wastewater ${ }^{8}$.

Several studies have been done to utilize wastewater from tofu industry to make products such as vitamin B12
${ }^{9-11)}$, bio-ethanol ${ }^{12)}$ and cultivation of micro algae ${ }^{13,14)}$. Several efforts have been conducted to treat tofu waste water via anaerobic processes in the fixed dome anaerobic and anaerobic baffled reactor ${ }^{15)}$ and the combination of anaerobic baffled and activated sludge system. However, the methods take more time which is about 12 to 78 days 16). The ozone method has also been conducted, in which the wastewater was diluted before being processed ${ }^{17,18)}$. This study proposed to treat the tofu wastewater via a combination of coagulation-flocculation and ultra filtration (UF) membrane separation processes so as the produced water meets the requirement of government regulation. The UF is chosen as the process is simple, energy efficient, and environmentally friendly ${ }^{19)}$.

\section{Materials and Methods}

This study uses a practical approach by using wastewater from a tofu industry in Lenteng Agung, Jakarta. The tofu wastewater is mixed with $\mathrm{NaOH}$ to adjust the $\mathrm{pH}$ to 7 , in order to achieve the best condition of coagulation and flocculation process, also to achieve the safety standard of tofu wastewater in Indonesia. The coagulant agent used in this study is alum, which has known to be one of the most popular coagulant-agent and has the advantageous of the wide range of spread in operational $\mathrm{pH}$. The amount of alum used is $300 \mathrm{ppm}$, or every $500 \mathrm{ml}$ wastewater, $3 \mathrm{ml}$ of solution containing $5 \%$ alum is used. The experiment was started by the process of flocculation-coagulation in Jar Test VELP JLT-6 at a 
speed of $120 \mathrm{rpm}$ for 2 minutes and continued at a speed of $40 \mathrm{rpm}$ for 10 minutes. The flocculation-coagulation process solution is then allowed to stand for half an hour before filtering using qualitative filter paper, where the filtrate was then processed in a membrane system. Polypropylene hollow-fiber membrane is used to perform the first stage of cleansing, and reverse osmosis membrane to perform the final stage filtration. The all observed parameters of the wastewater were measured before and after the coagulation-flocculation process and after the UF process. TSS and turbidity, $\mathrm{pH}$ and COD were measured using Colorimeter DR/890, Hanna Combo $\mathrm{pH}$ and EC, and UV beam UV-MS1 Single Beam Spectrophotometer.

Rejection rate, $R$, in the membrane processes for all observed parameters from the experiments can be calculated by:

$$
R=\frac{C_{i}-C_{f}}{C_{i}}
$$

where, $C_{\mathrm{i}}$ and $C_{\mathrm{f}}$ are initial and final concentration of the observed parameters, respectively. Meanwhile, the membrane flux, $J$, can be calculated by:

$$
J=\frac{Q}{A_{m}}
$$

where, $Q$ and $A_{\mathrm{m}}$ are permeate flow rate and surface area of the membrane, respectively.

\section{Results and Discussion}

The main goal of the tofu wastewater treatment in the study is to produce water which has parameter meet the requirement of the environmental quality standard based on Ministry of Environment Regulation No. 5 Year 2014 7). Due to the big excess of several parameters which has been stated by Indonesia's regulation, it can be concluded that the wastewater is harmful for environment. The tofu wastewater can pollute environment if it's being discharged directly to the water environment. Table 1 shows the characteristic of tofu waste water used in the experiment.

Table 1. Tofu wastewater characteristics

\begin{tabular}{|l|c|c|}
\hline $\begin{array}{c}\text { Observed } \\
\text { Parameters }\end{array}$ & $\begin{array}{c}\text { Concentration } \\
\text { range }\end{array}$ & $\begin{array}{c}\text { Government } \\
\text { Regulation }\end{array}$ \\
\hline$p H$ & $3.8-4.0$ & $6.0-9.0$ \\
\hline TDS (mg/L) & $850-880$ & 2000 \\
\hline TSS (mg/L) & $380-420$ & 100 \\
\hline Turbidity (FAU) & $450-530$ & 25 \\
\hline COD (mg/L) & $5600-6600$ & 275 \\
BOD (mg/L) & 4655 & 150 \\
\hline
\end{tabular}

The coagulant dose has a great influence on the effectiveness of the observed parameters reduction. TSS and turbidity are parameters that can be used as a reference in determining the efficiency of the coagulation process ${ }^{20)}$.
In plain view, the process can be observed with the formation of a white macroflock at the bottom of the solution after a process of settling for half an hour, and certainly produces a clearer solution than before. The measurement of TSS does not take place immediately after the jar test process, but rather after the filtering process using filter paper, with the aim of ensuring that the macroflock that are formed do not carry over into the subsequent process. This is important due to the presence of suspended solids in the solution can accelerate the process of fouling of the membrane in the UF process, which can shorten the life of the membrane. Figure 1 shows the reduction of TSS parameter and rejection rate at various coagulant dosage. In the coagulant range of 100 ppm to $800 \mathrm{ppm}$ with $100 \mathrm{ppm}$ increment, the results of TSS reduction were from $78 \%-84 \%$. The highest reduction achieved was $84 \%$ at 300 ppm dosage of coagulant. At the optimum condition, the suspended solid will be destabilized maximally so that the coagulation process can proceed effectively ${ }^{1)}$. The increase in TSS reduction efficiency with increasing coagulant doses is due to the increased concentration of metal ions available to neutralize negatively charged organic particles and form flocs ${ }^{21)}$. While a decrease in the efficiency of coagulation with increasing coagulant doses is associated with an increase in the zeta potential of surface colloids and retained particles ${ }^{22}$.

The treated wastewater at the optimum coagulationflocculation process was then used for the membrane process to the most effective trans-membrane-pressure (TMP) in the membrane processes. Figure 2 shows results of TSS, turbidity and $\mathrm{pH}$ of water produced in the UF process as a function of the TMP. The TSS and turbidity reductions decreases with increasing the TMP due to higher driving force in the UF process so that more suspended solids can pass through the UF membrane ${ }^{23,24)}$. Meanwhile, the $\mathrm{pH}$ of produced water from the UF process is relatively constants as shown in Fig. 2. The best TSS and turbidity from the UF process were $31 \mathrm{mg} / \mathrm{L}$ and 29 FAU and were achieved at TMP of 1 bar, while the $\mathrm{pH}$ was around 6.9. It is indicated that the TSS, turbidity and $\mathrm{pH}$ of the water produced from the UF process have meet the requirement of government regulation.



Fig. 1: Reduction of TSS as a function of alum dosage. 
The TDS and COD rejections in the UF process also have similar trend with TSS and turbidity where the TDS and COD increase with increasing TMP due to more driving force for the dissolved solid and organic matter can penetrate the UF membrane pores as presented in Fig. $3{ }^{25)}$. The lowest TDS and COD concentrations and reductions from the UF process were $1310 \mathrm{mg} / \mathrm{L}$ and 4385 $\mathrm{mg} / \mathrm{L}$ and $41.3 \%$ and $40.8 \%$, respectively, and were achieved at TMP of 1 bar. It reveals that the TDS of water produced in the UF process has meet the requirement of government regulation, while the COD still far above the regulation.

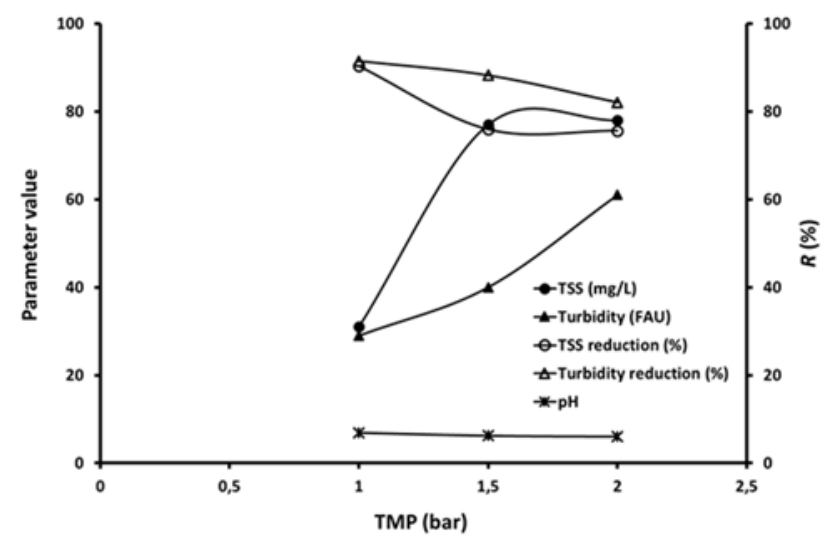

Fig. 2: TSS, turbidity and $p \mathrm{H}$ of water produced in the UF process.



Fig. 3: TDS and COD of water produced in the UF process.

Figure 4 shows the concentrations of all parameter observed in the water produced from the RO process. The feed water for RO process was taken from the best result in the UF process, which was water produced at the TMP of 1 bar. The increase in TMP in the RO process does not affect the ability of membrane to reduce TSS and turbidity of tofu wastewater. This is due to the membrane's ability far above the specifications needed to remove suspended solids and turbidity in the wastewater solution. Although the TMP is increased from 4 to 6 bar, the particle is not passed through the membrane as the particle size is much larger than the membrane pore size, indicating that the reverse osmosis membrane has a perfect level of effectiveness in removing the particles that cause TSS and turbidity. As presented in Fig. 4, the TSS and turbidity of the wastewater can be completely remove in the RO process, while the $\mathrm{pH}$ of water slightly decreases with TMP. Meanwhile, the TDS and the COD concentration decrease with increasing the TMP in the RO process, indicating that the RO membrane still can withstand the suspended solids and organic materials in the feed water at higher TMP applied in the experiments. The best rejection for TSS, turbidity, TDS and COD from the RO process were $100 \%, 100 \%, 99.89 \%$ and $99.86 \%$, respectively. The similar result also reported by Liu et al., where the COD of wastewater from textile effluent can be reduced to about $99.2 \%$ using RO membrane ${ }^{26)}$. The remain concentration of TDS and COD from the RO were $2 \mathrm{mg} / \mathrm{L}$ and $9 \mathrm{mg} / \mathrm{L}$, respectively, which have already met the requirement of the Government Regulation for Environmental Quality Standard. The previous study, which only used UF process still contain COD higher than the government regulation ${ }^{8)}$. The results of the all parameter observed in the study from the UF and RO processes were tabulated in Table 2.

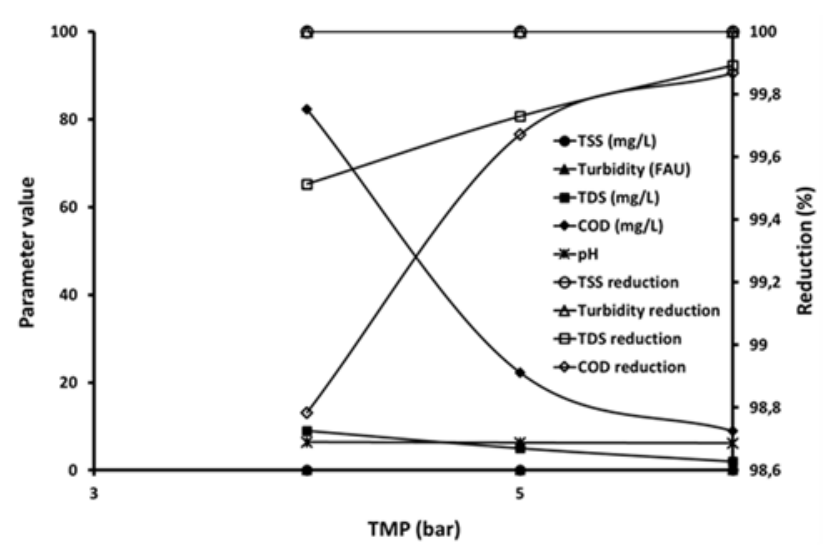

Fig. 4: TSS, turbidity, TDS, COD and $\mathrm{pH}$ of water produced in the RO process.

Table 2. The characteristics of tofu wastewater

\begin{tabular}{cccc}
\hline Parameter & $\begin{array}{c}\text { Government } \\
\text { Regulation }\end{array}$ & $\begin{array}{c}\text { UF } \\
\text { produced } \\
\text { water }\end{array}$ & $\begin{array}{c}\text { RO } \\
\text { produced } \\
\text { water }\end{array}$ \\
\hline$p \mathrm{H}$ & $6.0-8.0$ & 6.91 & 6.21 \\
TSS (mg/L) & 200 & 31 & 0 \\
Turbidity & 25 & 29 & 0 \\
(FAU) & & & \\
TDS (mg/L) & 2000 & 1310 & 2 \\
COD (mg/L) & 300 & 4385 & 9 \\
BOD (mg/L) & 150 & & 16 \\
\hline
\end{tabular}




\section{Conclusion}

The study has been conducted to find the optimum condition to treat tofu wastewater through combination of coagulation-flocculation and membrane process. The TSS can be removed more than $80 \%$ in the coagulationflocculation process suing alum at $300 \mathrm{ppm}$ dosage. In the UF process at TMP of 1 bar, all parameters observed in the study except COD have already met the standard stated by the government regulation. Afterward, in the RO process at the TMP of 6 bar the COD can be reduced drastically so that the water produced already comply with the government regulation. Therefore, the combination process of coagulation-flocculation, UF and RO can be employed to handle tofu wastewater in order to meet the discharged wastewater standards set by the government regulations. Further study can be conducted to use microfiltration (MF) membrane instead of UF membrane prior to RO process as the MF process consume less energy dan UF process.

\section{Acknowledgements}

Authors wish to acknowledge the financial support from the PIT 9 Project of the Universitas Indonesia through Contract No. NKB-0079/UN2.R3.1/HKP.05.00/2019.

\section{Nomenclature}

$\begin{array}{ll}C_{\mathrm{f}} & \begin{array}{l}\text { the final concentration of observed } \\ \text { papameters (mg L-1 or FAU) } \\ \text { the initial concentration of observed }\end{array} \\ C_{\mathrm{i}} & \begin{array}{l}\text { papameters (mg L } \mathrm{m}^{-1} \text { or FAU) } \\ \text { parameter reduction (-) }\end{array} \\ R & \end{array}$

\section{References}

1) Belén, F., Benedetti, S., Sánchez, J., Hernández, E., Auleda, J. M., Prudêncio, E. S., Petrus, J. C. C., Raventós, M. Behavior of functional compounds during freeze concentration of tofu whey. Journal of food engineering 116, 681-688 (2013).

2) Zhu, H., Ueda, S., Asada, Y. \& Miyake, J. Hydrogen production as a novel process of wastewater treatment-studies on tofu wastewater with entrapped R. sphaeroides and mutagenesis. International Journal of Hydrogen Energy 27, 13491357 (2002).

3) Perindustrian., K. (2016).

4) Belén, F., Sánchez, J., Hernández, E., Auleda, J. \& Raventós, M. One option for the management of wastewater from tofu production: Freeze concentration in a falling-film system. Journal of food engineering 110, 364-373 (2012).

5) Faisal, M., Gani, A., Mulana, F. \& Daimon, H. Treatment and Utilization of Industrial Tofu Waste in Indonesia. Asian Journal of Chemistry 28, 501 (2016).
6) Hidup, K.L. Peraturan menteri lingkungan hidup republik indonesia nomor 5 tahun 2014 tentang baku mutu air limbah. Jakarta (ID): Kementerian Lingkungan Hidup Republik Indonesia (2014).

7) Anggarini, S., Hidayat, N., Sunyoto, N.M.S. \& Wulandari, P.S. Optimization of Hydraulic Retention Time (HRT) and Inoculums Addition in Wastewater Treatment Using Anaerobic Digestion System. Agriculture and Agricultural Science Procedia 3, 95101 (2015).

8) Dwiki, S. Development of Environmental Policy in Indonesia regarding Mining Industry in Comparison with the United States and Australia: The Lesson That Can Be Learned. Evergreen 5, 50-57 (2018).

9) Yu, Y., Zhu, X., Shen, Y., Yao, H., Wang, P., Ye, K., Wang, X., Gu, Q. Enhancing the vitamin B12 production and growth of Propionibacterium freudenreichii in tofu wastewater via a light-induced vitamin B12 riboswitch. Applied microbiology and biotechnology 99, 10481-10488 (2015).

10) Yuwono, S.D. \& Kokugan, T. Study of the effects of temperature and $\mathrm{pH}$ on lactic acid production from fresh cassava roots in tofu liquid waste by Streptococcus bovis. Biochemical Engineering Journal 40, 175-183 (2008).

11) Zheng, G., Wang, L. \& Kang, Z. Feasibility of biohydrogen production from tofu wastewater with glutamine auxotrophic mutant of Rhodobacter sphaeroides. Renewable Energy 35, 2910-2913 (2010).

12) Febrianti, F., Syamsu, K. \& Rahayuningsih, M. Bioethanol Production from Tofu Waste by Simultaneous Saccharification and Fermentation (SSF) using Microbial Consortium. International Journal of Technology 5, 898-908 (2017).

13) Wang, S.-K., Wang, X., Miao, J. \& Tian, Y.-T. Tofu Whey Wastewater is a Promising Basal Medium for Microalgae Culture. Bioresource technology (2018).

14) Yonezawa, N., Matsuura, H., Shiho, M., Kaya, K. \& Watanabe, M.M. Effects of soybean curd wastewater on the growth and hydrocarbon production of Botryococcus braunii strain BOT-22. Bioresource technology 109, 304-307 (2012).

15) Faisal, M., Gani, A., Mulana, F. \& Daimon, H. Treatment and Utilization of Industrial Tofu Waste in Indonesia. Asian Journal of Chemistry 28 (2016).

16) Wagiman, A. \& Suryandono A tofu wastewater treatment with a combination of anaerobic baffled reactor and activated sludge system. Agritech $\mathbf{2 6}$ (2006).

17) Hadiyanto, H. in E3S Web of Conferences, Vol. 31 03002 (EDP Sciences, 2018).

18) Alhamid, M., Bismo, S., Ramadhan, I. \& Yatim, A. Study on the Effectiveness of Ozonation Technique in Preventing Scale Precipitation on Closed System Cooling Towers. Evergreen 6, 65-70 (2019).

19) Doraisammy, V., Lai, G. S., Kartohardjono, S., Lau, 
W. J., Chong, K. C., Lai, S. O., Hasbullah, H., Ismail, A. F. Synthesis and Characterization of Mixed Matrix Membranes Incorporated with Hydrous Manganese Oxide Nanoparticles for Highly Concentrated Oily Solution Treatment. The Canadian Journal of Chemical Engineering.

20) Haghiri, S., Daghighi, A. \& Moharramzadeh, S. Optimum coagulant forecasting by modeling jar test experiments using ANNs. Drinking Water Engineering and Science 11, 1-8 (2018).

21) Yan, M., Wang, D., Ni, J., Qu, J., Chow, C. W. K., Liu, H. Mechanism of natural organic matter removal by polyaluminum chloride: Effect of coagulant particle size and hydrolysis kinetics. Water research 42, 3361-3370 (2008).

22) Hossain, M.S. et al. Effective treatment of palm oil mill effluent using FeSO4. 7H2O waste from titanium oxide industry: Coagulation adsorption isotherm and kinetics studies. Journal of Cleaner Production 219, 86-98 (2019).

23) Aditya, I. \& Kartohardjono, S. in E3S Web of Conferences, Vol. 67 (2018).

24) Oktariany, A. \& Kartohardjono, S. in E3S Web of Conferences, Vol. 67 (2018).

25) Putri, S.S. \& Kartohardjono, S. in E3S Web of Conferences, Vol. 67 (2018).

26) Liu, M., Yu, C., Dong, Z., Jiang, P., Lü, Z., Yu, S., Gao, C. Improved separation performance and durability of polyamide reverse osmosis membrane in tertiary treatment of textile effluent through grafting monomethoxy-poly (ethylene glycol) brushes. Separation and Purification Technology 209, 443-451 (2019). 